\title{
ROBERT BLATCHFORD: NEGLECTED SOCIALIST
}

\author{
BY JOHN W. OSBORNE \\ John W. Osborne is a Rutgers English Professor of Emeritus \\ and a former editor of this journal.
}

Alexander Library has recently acquired thirty books written by the English socialist, Robert Blatchford (I85 I-I943). Blatchford was a journalist whose best known book, Merrie England, sold over two million copies after its publication in I893. He had considerable influence at the turn of this century on the founders of the Labour Party; at that time his name was more familiar than that of Karl Marx. Yet since Blatchford's death only one biography has been published, and perhaps no one of comparable importance in modern British history has been as neglected.

Blatchford was born in I85I, the year of the Great Exhibition, the first world's fair. A photograph taken of the opening ceremony in London shows a young Queen Victoria. When Blatchford died ninety-two years later in the midst of World War II, the battle of Stalingrad had been fought, and the atomic age would begin in two years. His unusually long life provides a reason for biographical neglect, as it is difficult to sustain interest in a writer whose best book was published a half century before his death. The course of Blatchford's life and work suggests some other reasons.

Blatchford's parents were actors. When Robert was two years of age his father died and he was brought up by his mother. Failing to gain steady employment, Blatchford joined the army when he was twenty years old and rose to the rank of sergeant major. The army was the source of his strong patriotism, and he drew on his military experience when he became a writer. After leaving the service he entered journalism. Writing about the Manchester slums turned him into a socialist. In 1890 he started a newspaper, The Clarion, and began to write fiction and books on topical subjects. By the end of the century, Blatchford had reached the peak of his influence. His writings were widely read and many people of importance in the Labour Party, including the future prime minister, Clement Attlee, later testified to his role in shaping their thought.

But after 1900, Blatchford's appeal began to wane. He lost some of his followers when he supported the British government over the Boer War (I899-I902), during which public opinion was sharply divided. His hostility toward organized religion and his negative attitude with respect to one of the major issues of the day, votes for women, also cost him support. The old 


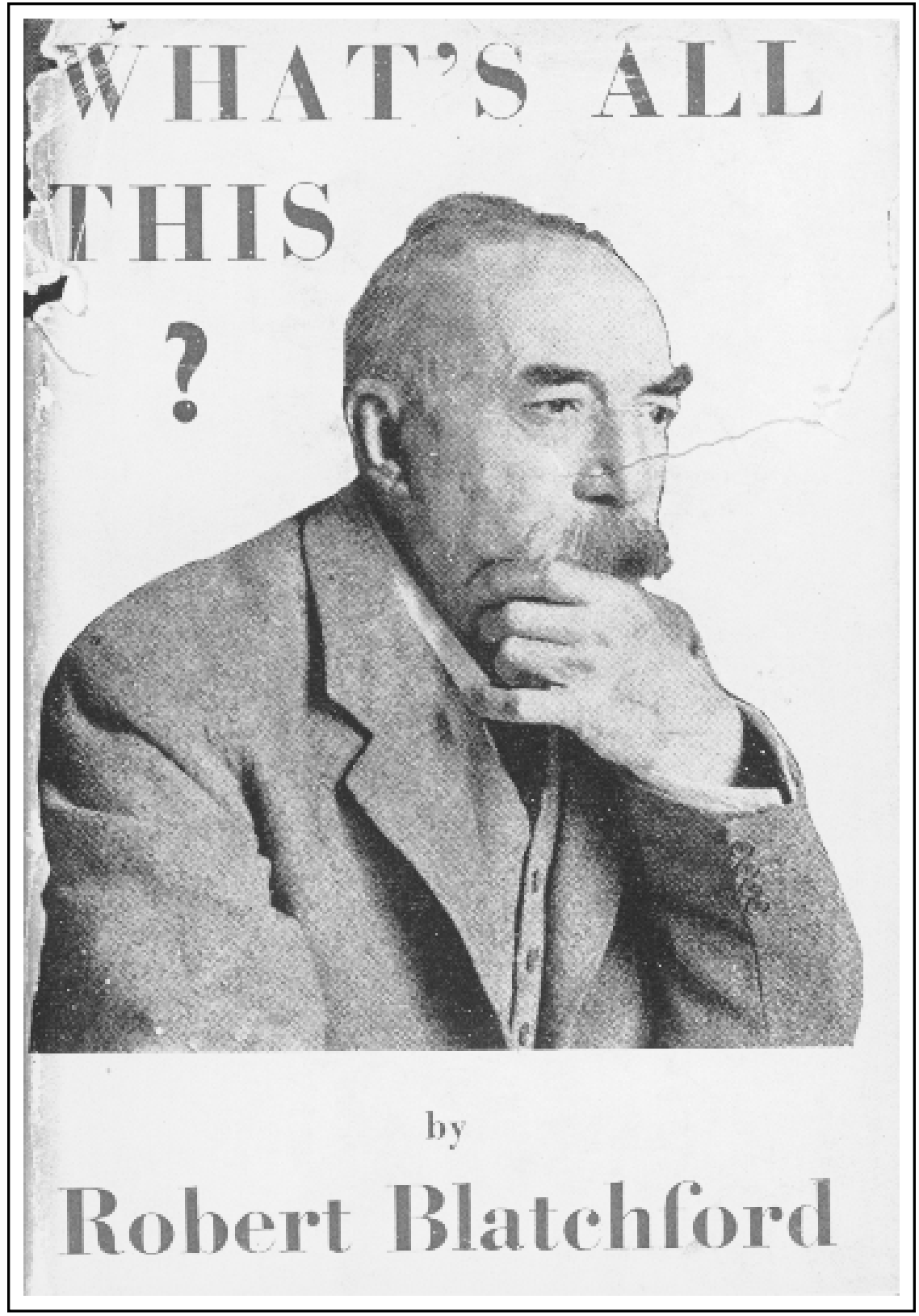

Figure 4.I Book jacket of What's All This? with the author's portrait 
soldier's patriotism and belief in individualism struggled against the current of an ever stronger Marxian socialism. After the First World War, Blatchford became even more nationalistic while his socialistic impulses grew weaker. The Clarion died slowly and did not expire until I935. (Sharp-eyed viewers of the I98I Academy Award film, Chariots of Fire, may have noticed an advertisement for The Clarion in the next-to-last scene, when one of the triumphant British athletes returned from the 1924 Olympic Games.)

Despite the long twilight of his career, Blatchford deserves to be remembered. Through The Clarion and his books, Blatchford suggested an unsystematic but positive variety of socialism which avoided malice and rancorous class consciousness. His simply written publications attracted readers who had benefited from the rapid growth of literacy after government reforms of education began in I870. These readers included ambitious members of the lower middle class and artisans who desired self-improvement. While advocating good nutrition, worthwhile literature, and exercise (especially the brand new pastime of cycling), Blatchford also urged his readers to avoid alcohol and tobacco.

Blatchford's socialism was personal, and his ideas were suggestive rather than detailed. He hated plutocratic greed and selfishness but wanted a more equal distribution of wealth to be achieved by legislation rather than force. He stressed worker self-improvement, not class consciousness. British to the core, he had no use for suggestions of a worldwide workers movement. After being warned of Germany's intentions before 19I4, he supported the British effort in the First World War.

It is pleasant to imagine the thrill experienced by clerks who were able to escape from stuffy, crowded London for a few hours by bicycling into the still unspoiled Surrey or Kent countryside. And Blatchford's advice concerning good literature helped industrial workers to spend their leisure time constructively. In this we see Blatchford's acknowledged indebtedness to the idea of his older socialist contemporary, William Morris, that life should be harmonious.

Labor unrest around 1910 caused British socialism to become more sharpedged. The I9I7 Bolshevik Revolution in Russia furthered this development, and after the war, militant, class-conscious Marxism became increasingly powerful. The decade of the 1920s in Great Britain, unlike in the United States, was marked by economic stagnation and a hardening of attitudes on the part of both management and labor. This distressed Blatchford, who now referred to himself as a Tory Democrat. He supported the emollient Conservative Prime Minister, Stanley Baldwin, who preached social harmony and the reconciliation of class differences. Blatchford was now regarded as an apostate by younger socialists, and this suggests another reason for historians' neglect of his career. His reputation suffered a similar fate as that of Ramsay 
MacDonald, the Labour Party Prime Minister in 1924 and 1929. After forming a coalition government with Conservatives in order to fight the Depression, MacDonald was vilified by his former comrades, and for forty years after his death, no adequate biography of him was published.

Blatchford's direct, confidential style of writing resembled that of another socialist, George Bernard Shaw, but Blatchford's was simpler and lacked Shaw's irony and range of vocabulary. Like George Orwell, Blatchford had faith in the good sense of working people, but he shrank from that willingness to confront harsh reality, which is a salient feature of the author of Homage to Catalonia and 1984. Some of Blatchford's views were similar to those of G.K. Chesterton's intrusive prejudices and artful use of paradox. Again, Blatchford's ideas were influenced by William Morris; he owed little or nothing to Karl Marx.

If anyone typified "socialism with a human face," it was Blatchford. He is an admirable figure for those who value human sympathy above logical rigor. Recently, the British Labour Party has modified considerably its attitude toward class struggle. Now it may be time for a thorough evaluation of the nonagenarian, whose homely appeals to the best in people, contrasting with the doctrinaire assertiveness of this century of ideology.

$4 x$

John Osborne donated the following books by and about Robert Blatchford to the Rutgers University Libraries:

Blatchford, Robert, As I Lay A-Thinking, London, Hodder and Stoughton, n.d., 304 pp.

McGinnis, P., pseudonym Blatchford, Robert, A Bohemian Girl, London, 1988, Clarion Newspaper, Walter Scott, Ltd., 252 pp.

Blatchford, Robert, A Book About Books, London, Clarion Press, I903, $254 \mathrm{pp}$.

Blatchford, Robert, Britain for the British, London, Clarion Press, I902, I73 pp.

Blatchford, Robert, Dismal England, London, Clarion Press, May I899, $240 \mathrm{pp}$.

Blatchford, Robert, Essays of To-Day and Yesterday, London, George G. Harrap \& Co., Ltd., I927, 6I pp.

Blatchford, Robert, General Von Sneak, London, Hodder \& Stoughton, Publishers, n.d., 179 pp.

Blatchford, Robert, Julie A Study of a Girl by a Man, London, Clarion

Press, n.d., 3 II pp.

Blatchford, Robert, Merrie England, New York, N.Y., Monthly

Review Press, I966, 252 pp. (two copies) 
Blatchford, Robert, My Eighty Years, Great Britain, Cassell \& Company Limited. I93I, 275 pp.

Blatchford, Robert, MyFavorite Books, London, Clarion Press, I90I, $253 \mathrm{pp}$.

Blatchford, Robert, My Life in the Army, London, Clarion Press, n.d., $310 \mathrm{pp}$.

Blatchford, Robert, Not Guilty, London, Clarion Press, I906, 26 I pp.

Blatchford, Robert, Saki's Bowl, London, Hodder \& Stoughton

Publishers, n.d., 320 pp.

Blatchford, Robert, Stunts, London, Clarion Press, n.d., 200 pp.

Blatchford, Robert, Tales for the Marines, London, Clarion Newspaper Co., Ltd., I901, 218 pp.

Blatchford, Robert, TheSorceryShop:AnImpossibleRomance, London, Clarion Press, 1907, 199 pp.

Blatchford,Robert, The War That WasForetold:Germany andEngland, Reprinted from "The Daily Mail" of 1909, 48 pp.

Blatchford, Robert, What's All This?, London, George Routledge \& Sons, Ltd., I940, 302 pp.

Where Are the Dead, London, Cassell and Company, Ltd., 1928, I36 pp. [Contains a chapter by Blatchford, "Secrets of Life and Love."] Thompson, Laurence, RobertBlatchford:PortraitofanEnglishman, London, Victor Gollancz, Ltd., I95I, 238 pp. 


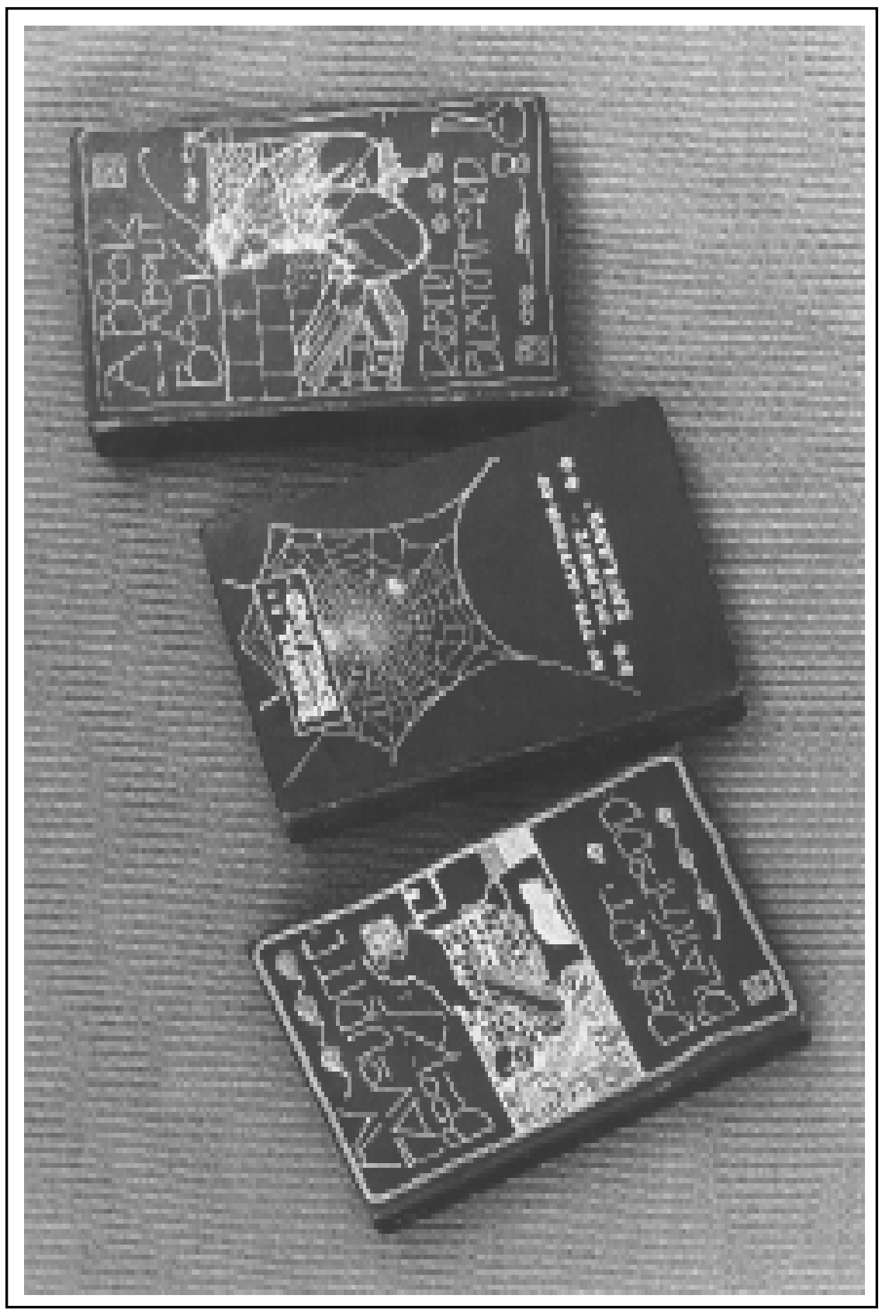

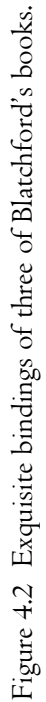

